\section{COHABITING COUPLES AND THE LAW - PAST, PRESENT AND FUTURE}

Aficionados of Sex and the City will be aware that the poor protection afforded to cohabiting couples is the mainspring for the plot of the recent movie, convincing the ultimate single girl Carrie Bradshaw to tie the knot with her longterm boyfriend. Those moving in with partners on this side of the Atlantic would be well advised to take heed, for here, too, protection remains limited.

Indeed, protection for cohabiting couples has always been limited in this jurisdiction. The idea that, prior to the Clandestine Marriages Act of 1753, such couples were regarded as having a "common-law marriage" and therefore entitled to the same rights as married couples is just as much a myth as the still-common belief that such an institution exists today. In fact, in the early eighteenth century those living together outside marriage were more likely to be ordered to do penance by the church courts than to be afforded any kind of legal recognition.

Such lack of protection did not constitute a pressing social problem for previous generations, given that cohabitation was relatively rare. While it is of course possible to find examples of cohabitation in every era - and the extent of cohabitation within the urban underclass of Victorian London was a particular concern of nineteenthcentury social commentators - in statistical terms cohabitation barely registered before the 1960s.

But that does not explain why cohabitants still lack legal protection. It is almost exactly 25 years since the Court of Appeal declared, in Burns v Burns, that the inadequacy of property law as a tool for dealing with the assets of cohabiting parties on relationship breakdown was a matter for Parliament to deal with, rather than the courts. A whole generation has been born, grown up, cohabited, and perhaps experienced the problems with the existing law for themselves in that period. Indeed, the issue has become even more pressing in recent years as a result of more couples cohabiting for longer periods, the expansion of home-ownership, and the increase in property prices: today, more cohabiting couples than ever are in the position of having assets worth fighting over.

Although one might regret the fact that the courts have not been able to develop more flexible remedies in this context, the decision of the House of Lords in Stack $v$ Dowden last year underlined the wisdom of leaving the matter to Parliament. The majority, led by Baroness Hale, argued that the courts should take responsibility for the evolution of the law in this area, and, in determining the shares that the parties owned, took a wide range of factors into account, including the way in which the parties had organised their finances. In the minority, however, Lord Neuberger counselled caution, noting that the risk that any change would result in "new and unforeseen uncertainties

\begin{tabular}{|c|c|}
\hline \multicolumn{2}{|l|}{ Articles } \\
\hline $\begin{array}{l}\text { Forgotten justice: forgetting law's hi } \\
\text { justice in British "minor" war crime } \\
\text { Germany 1945-8 }\end{array}$ & 2 \\
\hline $\begin{array}{l}\text { The Heritage Protection Bill: its effe } \\
\text { current systems }\end{array}$ & 11 \\
\hline Institute News & 14 \\
\hline \multicolumn{2}{|l|}{ Articles (cont'd) } \\
\hline $\begin{array}{l}\text { A curious episode in the history of } \\
\text { jurisdiction: the Supreme Court of } \\
\text { Act } 1873 \text { and ecclesiastical appeals }\end{array}$ & 17 \\
\hline Legal and responsible? & 24 \\
\hline
\end{tabular}

and unfairnesses" was particularly acute when such change was effected by the courts, which would be responding to the facts of the individual case and would not have the advantage of public consultation.

One might also add that the judiciary do not have the resources to research the way in which their decisions might affect cohabiting couples: since Stack, sociologists and lawyers researching in this area have pointed out that the way in which a couple organise their finances is not necessarily a good guide to their intentions vis-à-vis their shared home.

By contrast, the Law Commission's consultation paper on the appropriate remedy to be applied when a cohabiting relationship breaks down made extensive use of sociological research. Its subsequent report - Cohabitation: the Financial Consequences of Relationship Breakdown - was published in 2007 after public consultation. The scheme it proposed, while not without its difficulties, would have provided a remedy for many whose contributions and sacrifices are currently ignored by property law.

It therefore came as something of a disappointment when the Government announced in March 2008 that it would await the outcome of research on the scheme that had been implemented in Scotland before deciding what action to take in England and Wales. Still more disappointing was the implication that the cost of implementing the scheme would be a major factor in deciding on its future.

Yet the fact that large numbers might wish to take advantage of such a scheme is an argument in favour of reform, rather than the reverse. Hard cases may make bad law, but a sufficient accumulation of hard cases over the decades adds up to a compelling case for reform.

\section{Rebecca Probert \\ Associate Professor, University of Warwick}

